\title{
Effect of ascorbic acid and X-irradiation on HL-60 human leukemia cells: The kinetics of reactive oxygen species
}

\author{
SHINGO TERASHIMA ${ }^{1}$, YOICHIRO HOSOKAWA ${ }^{1}$, HIRONORI YOSHINO ${ }^{1}$, \\ MASARU YAMAGUCHI ${ }^{1}$ and TOSHIYA NAKAMURA ${ }^{2}$ \\ Departments of ${ }^{1}$ Radiological Life Sciences, ${ }^{2}$ Biomedical Sciences, Division of Medical Life Sciences, \\ Hirosaki University Graduate School of Health Sciences, Hirosaki, Aomori 036-8564, Japan
}

Received July 3, 2013; Accepted August 11, 2013

DOI: $10.3892 /$ or.2013.2758

\begin{abstract}
Ascorbic acid (AsA) treatment is expected to be a potential cancer therapy strategy with few side-effects that can be used alone or in combination with chemotherapy. However, the combination of AsA, a free radical scavenger, with radiation is not clearly understood; conflicting data are reported for cancer cell death. We conducted this study to determine the effect of AsA treatment combined with X-irradiation and the role of reactive oxygen species (ROS) in HL-60 human promyelocytic leukemia cells. Additive cytotoxic effects were observed when the cells were exposed to $2 \mathrm{~Gy} \mathrm{X}$-irradiation after $2.5 \mathrm{mM}$ AsA treatment. When catalase was added to the culture with AsA alone, the cytotoxic effects of AsA disappeared. X-irradiation increased intercellular ROS levels and mitochondrial superoxide levels. By contrast, AsA alone and in combination with $\mathrm{X}$-irradiation decreased ROS levels. However, in the presence of catalase neutralizing $\mathrm{H}_{2} \mathrm{O}_{2}$, AsA alone or in combination with $\mathrm{X}$-irradiation only slightly decreased the intercellular ROS. Moreover, AsA decreased the mitochondrial membrane potential, which is commonly associated with apoptosis. These results suggest that the reduction of ROS did not result from ROS scavenging by AsA, and AsA induced apoptosis through a ROS-independent pathway. This study reports that a combination of AsA with radiation treatment is effective in cancer therapy when considering ROS in cancer cells.
\end{abstract}

\section{Introduction}

Ascorbic acid (AsA) (also known as vitamin C) therapy has been considered a therapeutic option for cancer, and has few

Correspondence to: Professor Yoichiro Hosokawa, Department of Radiological Life Sciences, Division of Medical Life Sciences, Hirosaki University Graduate School of Health Sciences, 66-1 Honcho, Hirosaki, Aomori 036-8564, Japan

E-mail: hosokawa@cc.hirosaki-u.ac.jp

Key words: $\mathrm{X}$-irradiation, ascorbic acid, reactive oxygen species, cancer therapy side-effects when administered intravenously in pharmacologic concentrations (1). Chen et al reported that AsA is selectively toxic for some cancer cells but it is not toxic to normal cells (2). AsA exhibits cytotoxic effects in tumor cells, which have a low concentration of intracellular catalase that degrades hydrogen peroxide $\left(\mathrm{H}_{2} \mathrm{O}_{2}\right)$ (3). Studies have shown that tumor cells are easily damaged by $\mathrm{H}_{2} \mathrm{O}_{2}$, and production of the adenosine triphosphate (ATP) is decreased due to mitochondrial damage, thus leading to tumor cell death (3-7). $\mathrm{H}_{2} \mathrm{O}_{2}$ is produced during radiation therapy and some antineoplastic drugs kill the tumor cell by its cytotoxic activity (8). The generation of reactive oxygen species (ROS) derived from $\mathrm{H}_{2} \mathrm{O}_{2}$ is thought to be involved in the cytotoxicity. Vitamin $\mathrm{C}$ therapy can be used alone or in combination with chemotherapy (9-11). AsA in combination with radiation therapy is also expected to be effective in cancer therapy since it is considered to have few side-effects $(12,13)$. Koyama et al reported that AsA does not inhibit the fatal effects of radiation, but inhibits carcinogenesis and mutation (30). Therefore, AsA may reduce the risk of a second cancer in normal cells during combined AsA and radiation therapy.

AsA is also known as a radical scavenger $(14,15)$, and it scavenges $\mathrm{O}_{2}{ }^{\bullet}, \bullet \mathrm{OH},{ }^{1} \mathrm{O}_{2}$, and $\mathrm{NO}$ under in vitro conditions; thus, it can scavenge ROS generated by antineoplastic drugs or $\mathrm{X}$-irradiation (16). Therefore, conflicting data exist regarding AsA inhibiting the cytotoxic effects generated by the action of antineoplastic drugs or X-irradiation (17-21).

The majority of cell deaths induced by X-irradiation depend on the production of intracellular ROS, which is generated during irradiation. Within several hours after irradiation, secondary ROS production occurs intracellularly, and it induces apoptosis $(22,23)$. Mitochondria are well known as a major source of intracellular ROS and produce ROS during intracellular ATP synthesis. Therefore, the source of secondary ROS as a result of irradiation is thought to be the mitochondria (22-24). The generation of ROS from mitochondria and the loss of the mitochondrial membrane potential play an important role in inducing cell death $(23,25,26)$.

In this study, we examined the mechanism underlying cell death caused by a combination treatment of AsA and $\mathrm{X}$-irradiation from the viewpoint of ROS generation by using HL-60 human promyelocytic leukemia cells and we clarified that AsA does not inhibit the cytotoxic effects of X-irradiation. 


\section{Materials and methods}

Cell culture, X-irradiation, and drug treatment. The HL-60 human promyelocytic leukemia cell line (RIKEN BioResource Center, Tsukuba, Japan) was used in these experiments. Cells were cultured in RPMI-1640 (Gibco, Grand Island, NY, USA) supplemented with $10 \%$ fetal bovine serum and $1 \%$ penicillinstreptomycin, and were maintained at $37^{\circ} \mathrm{C}$ with $95 \%$ air and $5 \% \mathrm{CO}_{2}$. The passage duration was 3-5 days, and the density was not allowed to exceed $1 \times 10^{6}$ cells $/ \mathrm{ml}$. X-irradiation was delivered using an X-ray machine MBR-1520R-3 (Hitachi, Tokyo, Japan) at $150 \mathrm{kV}$ and $20 \mathrm{~mA}$ through a $0.5-\mathrm{mm} \mathrm{Al}$ and $0.3-\mathrm{mm} \mathrm{Cu}$ filter at a dose rate of $1.0 \mathrm{~Gy} / \mathrm{min}$. L(+)-ascorbic acid was purchased from Wako (Tokyo, Japan). The AsA was dissolved in RPMI-1640 medium and deacidified with sodium hydrate before treatment. Catalase (Sigma Aldrich, St. Louis, MO, USA) was added to the culture to achieve a final concentration of $1,300 \mathrm{U} / \mathrm{ml}$.

Cell viability assay. HL-60 cells $\left(4.0 \times 10^{5}\right.$ cells $\left./ \mathrm{ml}\right)$ were cultured for $6 \mathrm{~h}$. A final concentration of 0.01-10.0 mM AsA was then added to the culture and the number of viable cells was counted using trypan blue dye exclusion method after $24 \mathrm{~h}$. For the next experiment, $4 \times 10^{5}$ cells $/ \mathrm{ml}$ HL-60 cells were cultured with or without catalase for $6 \mathrm{~h}$, and 1.0 or $2.5 \mathrm{mM}$ AsA was added to the cells in combination with 2 Gy $\mathrm{X}$-irradiation. The viable cells were counted by trypan blue dye exclusion method after $24 \mathrm{~h}$.

Measurement of intracellular ROS. Subsequently, HL-60 cells $\left(1.5 \times 10^{5}\right.$ cells $\left./ \mathrm{ml}\right)$ were cultured with or without catalase for $6 \mathrm{~h}$, and $2.5 \mathrm{mM}$ AsA was added to the cells in combination with $2 \mathrm{~Gy} \mathrm{X}$-irradiation. The intracellular ROS production was measured using a flow cytometer (Cytomics FC500, Beckman Coulter, Fullerton, CA) using the ROS-sensitive probe 2'7-dichlorofluorescin diacetate $\left(\mathrm{H}_{2} \mathrm{DCFDA}\right.$; Molecular Probes, Invitrogen Corp., CA, USA) at the indicated times after exposure to $\mathrm{X}$-irradiation. The cells were washed with phosphate buffered saline without $\mathrm{Ca}^{2+}$ and $\mathrm{Mg}^{2+}$ [PBS(-)], incubated at $37^{\circ} \mathrm{C}$ with $5 \mu \mathrm{M} \mathrm{H}_{2} \mathrm{DCFDA}$ in PBS(-) for $15 \mathrm{~min}$, washed in PBS(-), and then resuspended in PBS(-) containing $5 \mathrm{mg} / \mathrm{l}$ propidium iodide (PI; Sigma Aldrich) to exclude dead cells. Sample data were analyzed using FlowJo software (Treestar, Inc., San Carlos, CA, USA). The median $\mathrm{H}_{2}$ DCFDA fluorescence intensity of each sample was normalized to that of control sample to calculate the relative $\mathrm{H}_{2}$ DCFDA intensity.

For the precise evaluation of ROS production immediately following X-irradiation, we labeled the cells with $\mathrm{H}_{2}$ DCFDA prior to AsA and $\mathrm{X}$-irradiation treatments $(27,28)$. In brief, cells were incubated at $37^{\circ} \mathrm{C}$ with $5 \mu \mathrm{M} \mathrm{H}_{2}$ DCFDA in PBS(-) for $15 \mathrm{~min}$. After labeling, the cells were treated with AsA and/or X-irradiation in the presence of $\mathrm{H}_{2} \mathrm{DCFDA}$, washed in PBS(-), and then resuspended in PBS(-) containing $5 \mathrm{mg} / \mathrm{l} \mathrm{PI}$. Samples were analyzed using a flow cytometer immediately after the treatment.

Measurement of mitochondrial superoxide and mitochondrial membrane potential. The cells were treated with AsA and/or $\mathrm{X}$-irradiation as described above without the addition of catalase. The mitochondrial superoxide levels were measured using

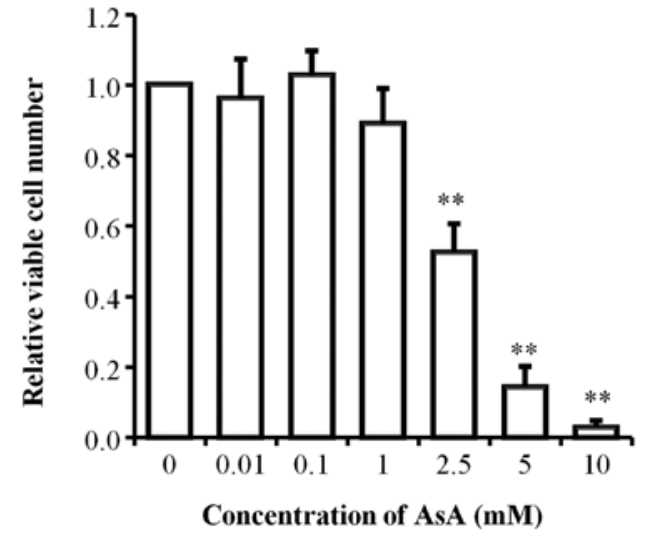

Figure 1. Relative viable cell number at $24 \mathrm{~h}$ after AsA treatment. ${ }^{* *} \mathrm{p}<0.01$ vs. $0 \mathrm{mM}$. AsA showed cytotoxic effects on the growth of HL-60 cells in a dose-dependent manner from $\sim 1 \mathrm{mM}$.

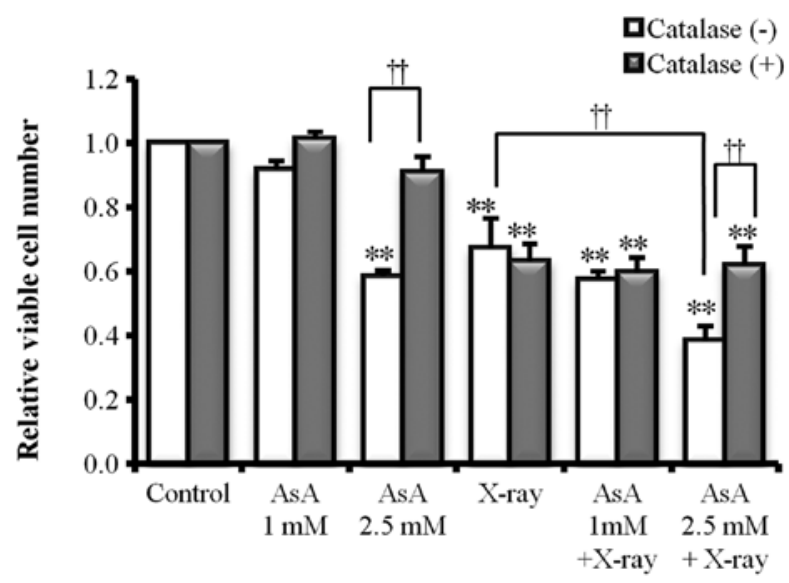

Figure 2. Relative viable cell number at $24 \mathrm{~h}$ after $\mathrm{X}$-ray irradiation (2 Gy), AsA treatment ( 1 or $2 \mathrm{mM}$ ), and combined X-ray and AsA treatment (white bars, untreated with catalase; gray bars, treated with catalase). ${ }^{* *} \mathrm{p}<0.01 \mathrm{vs} .0 \mathrm{mM}$. ${ }^{\dagger} \mathrm{p}<0.01$.

the flow cytometer with mitochondrial superoxide indicator MitoSOX Red (Molecular Probes, Invitrogen Corp.) at the indicated times after exposure to $\mathrm{X}$-irradiation. The cells were washed with PBS(-), incubated at $37^{\circ} \mathrm{C}$ with $5 \mu \mathrm{M}$ MitoSOX Red in Hanks' Balanced Salt Solutions (HBSS; with $\mathrm{Ca}^{2+}$ and $\mathrm{Mg}^{2+}$ ) for the $15 \mathrm{~min}$, and then washed and resuspended in PBS(-). Sample data were analyzed using the FlowJo software. The median MitoSOX Red fluorescence intensity of each sample was normalized to that of control sample to calculate the relative MitoSOX Red intensity.

The changes in the mitochondrial membrane potential were measured using the flow cytometer with 3,3'-dihexyloxacarbocyanine iodide [DiOC6(3)]; Molecular Probes, Invitrogen Corp.) at indicated times after exposure to X-irradiation. The cells were washed with $\mathrm{PBS}(-)$, incubated at $37^{\circ} \mathrm{C}$ with $40 \mathrm{nM}$ $\mathrm{H}_{2}$ DCFDA in HBSS for $15 \mathrm{~min}$, washed in HBSS, and then resuspended in serum-free RPMI-1640 medium containing $5 \mathrm{mg} / \mathrm{l}$ PI to exclude dead cells. Sample data were analyzed using FlowJo software. The median DiOC6(3) fluorescence intensity of each sample was normalized to that of control sample to calculate the relative DiOC6(3) intensity. 
A
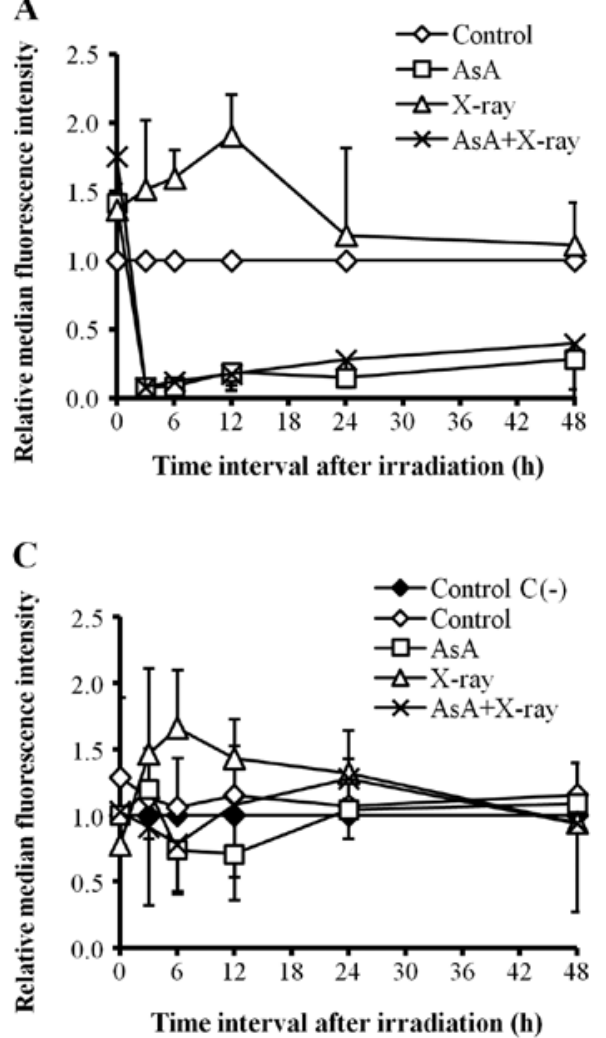

B

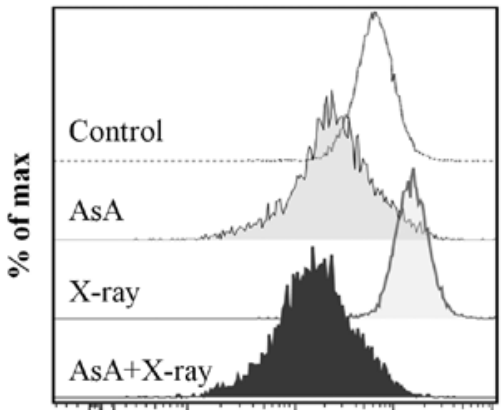

Fluorescence intensity

D

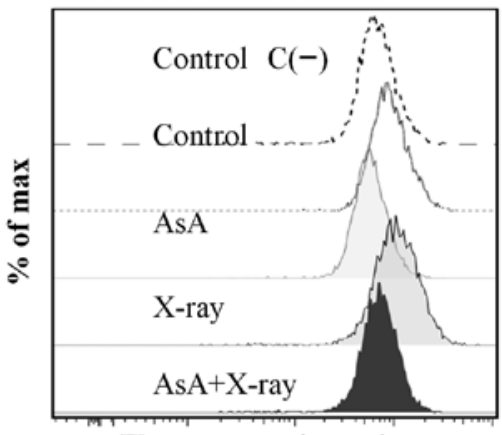

Fluorescence intensity

Figure 3. Kinetics of intracellular ROS production analyzed by flow cytometry using $\mathrm{H}_{2}$ DCFDA. Intracellular ROS levels without catalase (A) and with catalase (C) after X-irradiation. A representative flow cytometric histogram of $\mathrm{H}_{2} \mathrm{DCFDA}$ fluorescence intensity at $12 \mathrm{~h}$ without catalase (B) and at $6 \mathrm{~h}$ with catalase (D) after X-irradiation. Control C(-) represents control in the absence of catalase.

Statistical analysis. Statistical comparisons were performed using the Tukey-Kramer test. All results are presented as the mean \pm SD from the results of at least three independent experiments. p-values $>0.01$ or 0.05 were considered to indicate statistically significant differences. Statistical analysis was performed using the Excel 2007 software program (Microsoft, USA) with Statcel 2 add-in software (29).

\section{Results}

Cell death by AsA treatment and X-irradiation. In the initial experiment, we examined the AsA sensitivity of HL-60 cells. After AsA treatment for $24 \mathrm{~h}$, we counted the viable HL-60 cells by trypan blue dye exclusion method. AsA showed cytotoxic effects on the growth of HL-60 cells in a dose-dependent manner from $\sim 1 \mathrm{mM}$ concentration (Fig. 1). Enhanced cell growth was not observed in AsA treatment at low concentrations $(0.01$ or $0.1 \mathrm{mM})$.

Additive cytotoxic effects were observed when the cells were exposed to $2 \mathrm{~Gy} \mathrm{X}$-irradiation after $2.5 \mathrm{mM}$ AsA treatment (Fig. 2). When $2.5 \mathrm{mM}$ AsA and 2 Gy X-irradiation were used in combination, a significant decrease in the relative viable cell number was observed when compared to application of 2 Gy X-irradiation alone ( $\mathrm{p}<0.05)$. Fig. 2 also shows the cytotoxic effect of AsA alone and in combination with $\mathrm{X}$-irradiation in the presence of catalase. When AsA was added to the culture in the presence of catalase, the cytotoxic effects of AsA disappeared. Moreover, the additive cytotoxic effects of $2.5 \mathrm{mM}$ AsA and 2 Gy X-irradiation in combina- tion decreased to the same level as those obtained by $2 \mathrm{~Gy}$ $\mathrm{X}$-irradiation alone.

Kinetics of intracellular ROS. Fig. 3A shows the changes in intracellular ROS levels as analyzed using a flow cytometer. In cells treated with $\mathrm{X}$-irradiation alone ( $2 \mathrm{~Gy}$ ), the intracellular ROS levels increased and reached a peak at $12 \mathrm{~h}$ $(\mathrm{p}<0.01)$ compared to control, and decreased slowly thereafter. By contrast, treatment with AsA alone $(2.5 \mathrm{mM})$ and in combination with X-irradiation (2 Gy) significantly decreased intracellular ROS levels at 3-24 h after X-irradiation. A representative histogram of DCF fluorescence intensity at $12 \mathrm{~h}$ is shown in Fig. 3B.

Fig. 3C shows the changes in the intracellular ROS levels in the presence of catalase. The intracellular ROS levels of $\mathrm{X}$-irradiated cells increased slightly and reached a peak after $6 \mathrm{~h}$, but there was no significant difference when compared to control cells. The ROS levels of cells treated with AsA alone and in combination with $\mathrm{X}$-irradiation were also not significantly altered compared to those of the control cells. A representative histogram of DCF fluorescence intensity at $6 \mathrm{~h}$ is shown in Fig. 3D.

In the absence of catalase, the ROS levels of cells treated with a combination of AsA and X-irradiation were significantly higher than those of the control cells at $0 \mathrm{~h}$ after $\mathrm{X}$-irradiation, and this difference was statistically significant $(\mathrm{p}<0.05)$. For the precise evaluation of ROS production immediately following $\mathrm{X}$-irradiation, we labeled the cells with $\mathrm{H}_{2}$ DCFDA prior to AsA and X-irradiation treatment. The ROS levels of cells 
A

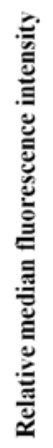

$$
\begin{aligned}
& 4 \\
& 3 \\
& 2 \\
& 1 \\
& 0 \\
& 0 \\
& 0
\end{aligned}
$$

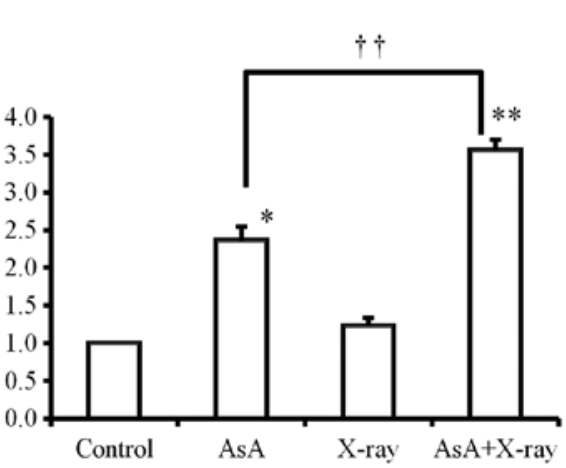

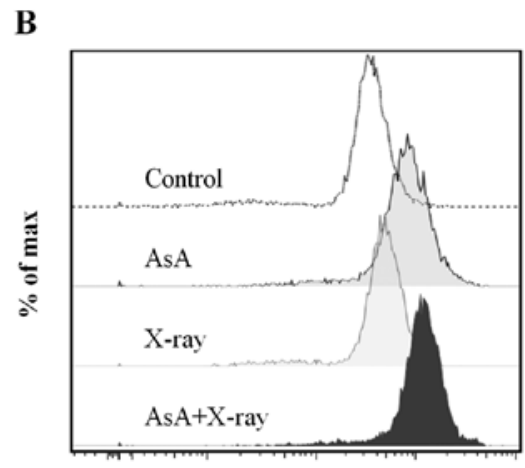

Fluorescence intensity

Figure 4. Evaluation of ROS production soon after X-irradiation. We labeled the cells with $\mathrm{H}_{2} \mathrm{DCFDA}$ before AsA and X-irradiation treatment. After AsA and/or X-irradiation, samples were run on a flow cytometer immediately. (A) ROS production immediately following X-irradiation. (B) A representative flow cytometric histogram of $\mathrm{H}_{2}$ DCFDA fluorescence intensity immediately following X-irradiation. ${ }^{*} \mathrm{p}<0.05 \mathrm{vs} .0 \mathrm{mM},{ }^{* * *} \mathrm{p}<0.01 \mathrm{vs} .0 \mathrm{mM}$. ${ }^{\dagger \dagger} \mathrm{p}<0.01$.
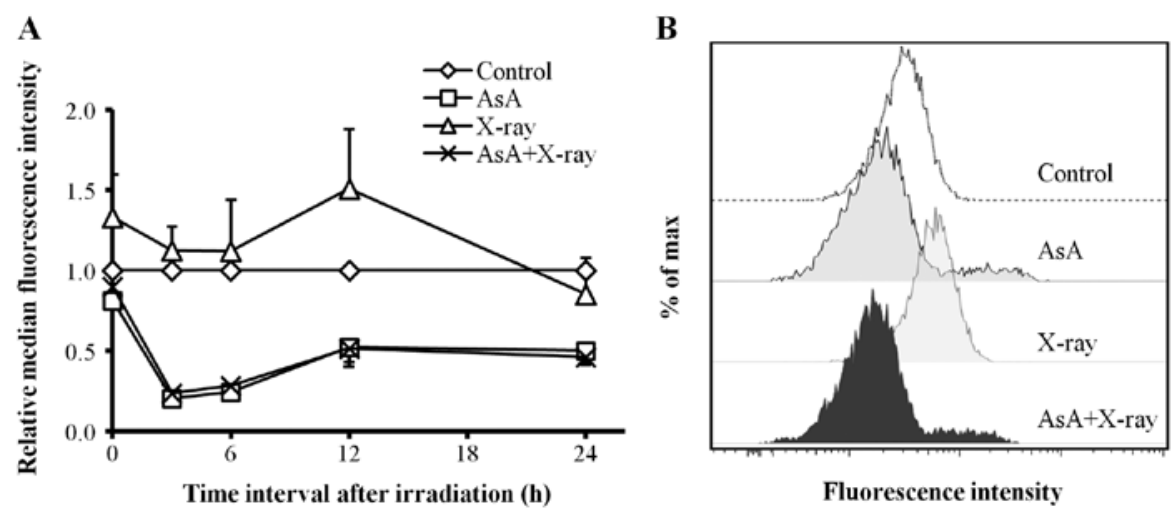

Figure 5. Mitochondrial superoxide analysis by flow cytometry using MitoSOX Red. (A) Kinetics of mitochondrial superoxide. (B) A representative flow cytometric histogram of MitoSOX Red fluorescence intensity at $12 \mathrm{~h}$ after X-irradiation.

treated with AsA alone and in combination with X-irradiation significantly increased immediately following X-irradiation, compared to control cells (Fig. 4A and B).

Kinetics of mitochondrial superoxide and mitochondrial membrane potential. The changes in mitochondrial superoxide levels were analyzed by flow cytometry (Fig. 5A). When X-irradiation was used alone, mitochondrial superoxide levels increased slightly and reached a peak at $12 \mathrm{~h}(\mathrm{p}<0.01)$ compared to control (Fig. 5B). By contrast, AsA alone and in combination with $\mathrm{X}$-irradiation significantly decreased the mitochondrial superoxide levels at 3-24 h after X-irradiation. These changes were similar to the changes in the intracellular ROS levels.

In order to investigate whether AsA scavenged intracellular ROS or whether generation of ROS from mitochondria was decreased, we used DiOC6(3) (a carbocyanine dye that accumulates in active mitochondria) to measure the mitochondrial membrane potential by flow cytometry. When X-irradiation was used alone, the mitochondrial membrane potential increased slightly and reached a peak at $12 \mathrm{~h}(\mathrm{p}<0.01)$ compared to control (Fig. 6A). Contrary to this, in the presence of only AsA or in combination with X-irradiation, the mitochondrial membrane potential gradually decreased and became $~ 40 \%$ of control value at $12 \mathrm{~h}$ after $\mathrm{X}$-irradiation (Fig. 6B).

\section{Discussion}

In the present study, we described the potential of AsA and $\mathrm{X}$-irradiation combination treatment, particularly against intracellular ROS in HL-60 cells. We demonstrated that AsA, a radical scavenger, did not inhibit the cytotoxic effect when used in combination with $\mathrm{X}$-irradiation although it resulted in intracellular ROS reduction.

In this study, additive cytotoxic effects were observed when the cells were exposed to $2 \mathrm{~Gy}$ X-irradiation after $2.5 \mathrm{mM}$ AsA treatment. When a combination of $1 \mathrm{mM}$ AsA and 2 Gy X-irradiation was applied, the protective effect of AsA against 2 Gy $\mathrm{X}$-irradiation was not observed and no significant cytotoxic effects were found. These results are consistent with the studies that AsA does not inhibit the fatal effects of radiation $(12,30)$. When AsA was added to the culture in the presence of catalase, the cytotoxic effects of AsA disappeared. Moreover, the additive cytotoxic effects decreased to the same level obtained by $\mathrm{X}$-irradiation alone. These results suggest that the action pathway of hydroxyl radicals derived from $\mathrm{H}_{2} \mathrm{O}_{2}$ is different in AsA and X-irradiation treatments. Catalase, being a large protein, does not penetrate cell membranes and, therefore, it is not taken up by cells. Catalase neutralizes the $\mathrm{H}_{2} \mathrm{O}_{2}$ derived from AsA in the extracellular fluids. Therefore, it is considered that the cytotoxic effect of extracellular $\mathrm{H}_{2} \mathrm{O}_{2}$ 
A

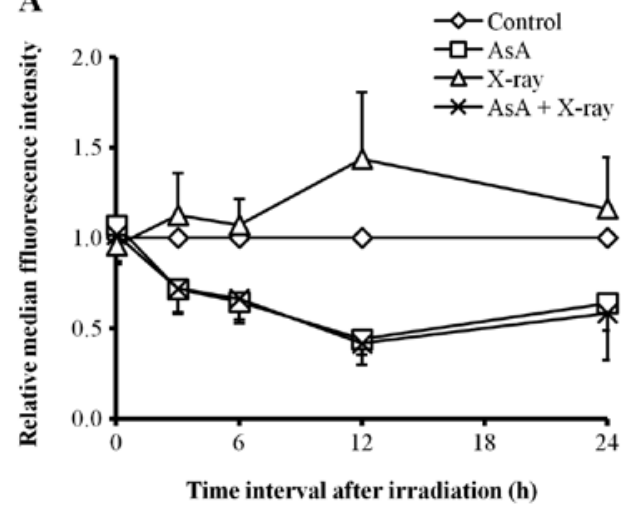

B

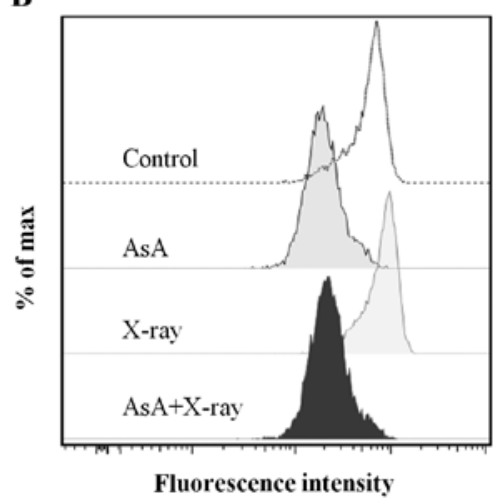

Figure 6. Mitochondrial membrane potential analyzed by flow cytometry by using DiOC6(3). (A) Kinetics of mitochondrial membrane potential. (B) A representative flow cytometric histogram of DiOC6(3) fluorescence intensity at $12 \mathrm{~h}$ after X-irradiation.

that AsA generates is much more effective than the cytotoxic effect of intracellular AsA $(3,31)$.

Our present study showed that AsA significantly decreased intercellular ROS production. Hence, such a result might indicate that combined AsA and X-irradiation treatment may not be effective as cell death due to signal transduction by ROS is inhibited (20,21). In AsA treatment, a significant change in the intercellular ROS level was not observed in the presence of catalase as compared with the significant reduction of intracellular ROS in the absence of catalase. For this reason, our results suggest that the slight change in intracellular ROS is due to the neutralizing effect of extracellular $\mathrm{H}_{2} \mathrm{O}_{2}$ by catalase in preference to scavenging intercellular ROS by AsA. It is thought that extracellular $\mathrm{H}_{2} \mathrm{O}_{2}$ generated by AsA treatment might mainly decrease intercellular ROS or both cytotoxic effects and radical scavenger are necessary for significant reduction of ROS. Some studies have reported that antineoplastic drugs exhibit cytotoxic effects with reduction of ROS; hence, it showed the ability of scavenging ROS such as AsA $(32,33)$. It was also reported that intercellular ROS slightly decreased when cells were treated with $\mathrm{H}_{2} \mathrm{O}_{2}$ (34).

When AsA alone and in combination with $\mathrm{X}$-irradiation was used, large quantities of intracellular ROS were observed immediately following AsA and X-irradiation treatment, which was observed by labeling the cells with $\mathrm{H}_{2}$ DCFDA prior to treatment. It is reported that $\mathrm{H}_{2} \mathrm{O}_{2}$ generation was dependent on the presence of trace amounts of serum in media (2). When the cells were treated with AsA and/or X-irradiation in the presence of $\mathrm{H}_{2}$ DCFDA in $10 \%$ FBS growth medium, but not in PBS, 12-fold ROS production in the control was observed for AsA alone and in combination with X-irradiation (data not shown). Since $\mathrm{H}_{2} \mathrm{O}_{2}$ can easily permeate cell membranes (35), large quantities of $\mathrm{H}_{2} \mathrm{O}_{2}$ derived from AsA might damage HL-60 cells immediately following AsA treatment, after which the intercellular ROS production is decreased. Frömberg et al showed that AsA or dehydroascorbate (DHA) is important for cytotoxic efficiency in the redox state of vitamin $\mathrm{C}$, and they report higher therapeutic efficacy of AsA over DHA in various cell lines (31). Furthermore, it was reported that tumor cells take up DHA, but not AsA, in large quantities. However, a moderate change in the intracellular ROS levels was observed in the order of mM DHA (18), although DHA turn into AsA in cells (16), contrary to our results of AsA treatment. Therefore, the redox state of vitamin $\mathrm{C}$ agents may lead to contradictory results in vitamin $\mathrm{C}$ treatment.

Mitochondria release cytochrome $c$, which activates caspase for apoptosis, leading to changes in mitochondrial respiratory chain, and the mitochondrial membrane potential is depolarized. Therefore, mitochondrial membrane potential is used as an indicator for evaluating cell life and death (36). In our study, mitochondrial membrane potential gradually disappeared in cells treated with AsA. However, it is reported that an increase in intracellular ROS is observed when the mitochondrial membrane potential is decreased by several antineoplastic agents (37). Some studies reported the existence of ROS-independent mitochondrial pathway, since reduction of the mitochondrial membrane potential is observed without an increase in intracellular ROS $(32,33,38,39)$. AsA might induce apoptosis in HL-60 cells through a ROS-independent mitochondrial pathway as intracellular ROS was significantly decreased as compared with the control, and a reduction in the mitochondrial membrane potential was observed in AsA treatment.

Some studies reported that the antineoplastic agent that has the ability of scavenging ROS induces apoptosis through a ROS-independent mitochondrial pathway with reduction in ROS $(32,33)$. Furthermore, an increase in intracellular ROS and superoxide levels derived from mitochondria was reported and mitochondrial membrane potential hyperpolarization was observed after X-ray irradiation. It is thought that X-irradiation arrests cell cycle, inhibits cell division and increases in the mitochondrial content, leading to the activation of mitochondrial respiratory chain, resulting in the increase of mitochondrial ROS $(24,40)$. Our data are consistent with these studies, but changes in the X-ray irradiated cells were contrary to the changes in cells treated with AsA. When a combination of AsA and X-irradiation was used, ROS levels decreased to the same level obtained by AsA alone, but AsA did not inhibit the cytotoxic effects of X-irradiation. While considering ROS generation, these indicate that additive cytotoxic effects were observed since AsA and X-irradiation follow different signaling pathways. Shinozaki et al reported that the involvement of Bax and caspase 8 were different following $\mathrm{X}$-irradiation or AsA treatment alone as compared with those following combined X-irradiation and AsA treatment against the apoptosis mechanism (12). 
In the present study, we examined the mechanism underlying cell death caused by a combination of AsA and $\mathrm{X}$-irradiation from the viewpoint of ROS generation by HL-60 cells to reveal the clinical possibility of a combination therapy. The combination decreased intracellular ROS generation, but additive cytotoxic effects and reduction of mitochondrial membrane potential were observed in cells. These results suggest that AsA, which is a radical scavenger, did not exert protective effects against ROS production by $\mathrm{X}$-irradiation and the signaling pathway in mitochondria was different for AsA and X-irradiation. Our results suggest that combination therapy of AsA and X-irradiation does not have an effect on cancer cell death while considering ROS generation.

\section{References}

1. Padayatty SJ, Sun AY, Chen Q, Espey MG, Drisko J and Levine M: Vitamin C: intravenous use by complementary and alternative medicine practitioners and adverse effects. PLoS One 5: e11414, 2010.

2. Chen Q, Espey MG, Krishna MC, et al: Pharmacologic ascorbic acid concentrations selectively kill cancer cells: action as a pro-drug to deliver hydrogen peroxide to tissues. Proc Natl Acad Sci USA 102: 13604-13609, 2005.

3. Chen Q, Espey MG, Sun AY, et al: Ascorbate in pharmacologic concentrations selectively generates ascorbate radical and hydrogen peroxide in extracellular fluid in vivo. Proc Natl Acad Sci USA 104: 8749-8787, 2007.

4. Takemura Y,Satoh M, Satoh K, Hamada H, Sekido Y and Kubota S: High dose of ascorbic acid induces cell death in mesothelioma cells. Biochem Biophys Res Commun 394: 249-253, 2010.

5. Hsieh BS, Huang LW, Su SJ, et al: Combined arginine and ascorbic acid treatment induces apoptosis in the hepatoma cell line HA22T/VGH and changes in redox status involving the pentose phosphate pathway and reactive oxygen and nitrogen species. J Nutr Biochem 22: 234-241, 2011.

6. Hampton MB and Orrenius S: Dual regulation of caspase activity by hydrogen peroxide: implications for apoptosis. FEBS Lett 414 : 552-556, 1997.

7. Hyslop PA, Hinshaw DB, Halsey WA Jr, et al: Mechanisms of oxidant-mediated cell injury. The glycolytic and mitochondrial pathways of ADP phosphorylation are major intracellular targets inactivated by hydrogen peroxide. J Biol Chem 263: 1665-1675, 1998.

8. Lamson DW and Brignall MS: Antioxidants in cancer therapy; their actions and interactions with oncologic therapies. Altern Med Rev 4: 304-329, 1999.

9. Padayatty SJ, Riordan HD, Hewitt SM, Katz A, Hoffer LJ and Levine M: Intravenously administered vitamin $\mathrm{C}$ as cancer therapy: three cases. CMAJ 174: 937-942, 2006.

10. Riordan HD, Casciari JJ, González MJ, et al: A pilot clinical study of continuous intravenous ascorbate in terminal cancer patients. PR Health Sci J 24: 269-276, 2005.

11. Monti DA, Mitchell E, Bazzan AJ, et al: Phase I evaluation of intravenous ascorbic acid in combination with gemcitabine and erlotinib in patients with metastatic pancreatic cancer. PLoS One 7: e29794, 2012.

12. Shinozaki K, Hosokawa Y, Hazawa M, et al: Ascorbic acid enhances radiation-induced apoptosis in an HL60 human leukemia cell line. J Radiat Res 52: 229-237, 2011

13. Herst PM, Broadley KW, Harper JL and McConnell MJ: Pharmacological concentrations of ascorbate radiosensitize glioblastoma multiforme primary cells by increasing oxidative DNA damage and inhibiting G2/M arrest. Free Radic Biol Med 52: 1486-1493, 2012.

14. Rose RC and Bode AM: Biology of free radical scavengers: an evaluation of ascorbate. FASEB J 7: 1135-1142, 1993.

15. Li Y and Schellhorn HE: New developments and novel therapeutic perspectives for vitamin C. J Nutr 137: 2171-2184, 2007.

16. Reth M: Antioxidant defenses - endogenous and diet derived. In: Free Radicals in Biology and Medicine. Halliwell B and Gutteridge JMC (eds). 4th edition. Oxford University Press, New York, pp160-166, 2007.
17. Lawenda BD, Kelly KM, Ladas EJ, Sagar SM, Vickers A and Blumberg JB: Should supplemental antioxidant administration be avoided during chemotherapy and radiation therapy? J Natl Cancer Inst 100: 773-783, 2008.

18. Heaney ML, Gardner JR, Karasavvas N, et al: Vitamin C antagonizes the cytotoxic effects of antineoplastic drugs. Cancer Res 68: 8031-8038, 2008.

19. Yamamoto T, Kinoshita M, Shinomiya N, et al: Pretreatment with ascorbic acid prevents lethal gastrointestinal syndrome in mice receiving a massive amount of radiation. J Radiat Res 51: 145-156, 2010.

20. Witenberg B, Kalir HH, Raviv Z, Kletter Y, Kravtsov V and Fabian I: Inhibition by ascorbic acid of apoptosis induced by oxidative stress in HL-60 myeloid leukemia cells. Biochem Pharmacol 57: 823-832, 1999.

21. Witenberg B, Kletter Y, Kalir HH, et al: Ascorbic acid inhibits apoptosis induced by X irradiation in HL60 myeloid leukemia cells. Radiat Res 152: 468-478, 1999.

22. Lee YJ,Lee DH, Cho CK, et al: HSP2 5 inhibits radiation-induced apoptosis through reduction of PKC $\delta$-mediated ROS production. Oncogene 24: 3715-3725, 2005.

23. Ni Y, Gong XG, Lu M, Chen HM and Wang Y: Mitochondrial ROS burst as an early sign in sarsasapogenin-induced apoptosis in HepG2 cells. Cell Biol Int 32: 337-343, 2008.

24. Ogura A, Oowada S, Kon Y, et al: Redox regulation in radiationinduced cytochrome c release from mitochondria of human lung carcinoma A549 cells. Cancer Lett 277: 64-71, 2009.

25. Grad JM, Cepero E and Boise LH: Mitochondria as targets for established and novel anti-cancer agents. Drug Resist Updat 4: 85-91, 2001.

26. Green DR and Reed JC: Mitochondria and apoptosis. Science 281: 1309-1312, 1998

27. Yoshino H, Kiminarita T, Matsushita Y and Kashiwakura I: Response of the Nrf2 protection system in human monocytic cells after ionising irradiation. Radiat Prot Dosimetry 152: 104-108, 2012.

28. Hachiya $\mathrm{M}$ and Akashi M: Catalase regulates cell growth in HL60 human promyelocytic cells: evidence for growth regulation by $\mathrm{H}_{2} \mathrm{O}_{2}$. Radiat Res 163: 271-282, 2005.

29. Yanai H: Statcel-The Useful Add-in Software Forms on Excel. 2nd edition. OMS, Tokyo, 2006.

30. Koyama S, Kodama S, Suzuki K, Matsumoto T, Miyazaki T and Watanabe M: Radiation-induced long-lived radicals which cause mutation and transformation. Mutat Res 421: 45-54, 1998.

31. Frömberg A, Gutsch D, Schulze D, et al: Ascorbate exerts antiproliferative effects through cell cycle inhibition and sensitizes tumor cells towards cytostatic drugs. Cancer Chemother Pharmacol 67: 1157-1166, 2011.

32. Wang XH, Jia DZ, Liang YJ, et al: Lgf-YL-9 induces apoptosis in human epidermoid carcinoma KB cells and multidrug resistant KBv200 cells via reactive oxygen species-independent mitochondrial pathway. Cancer Lett 249: 256-270, 2007.

33. Zhang JY, Wu HY, Xia XK, et al: Anthracenedione derivative $1403 \mathrm{P}-3$ induces apoptosis in KB and KBv200 cells via reactive oxygen species-independent mitochondrial pathway and death receptor pathway. Cancer Biol Ther 6: 1413-1421, 2007.

34. Lin KT, Xue JY, Sun FF and Wong PY: Reactive oxygen species participate in peroxynitrite-induced apoptosis in HL-60 cells. Biochem Biophys Res Commun 230: 115-119, 1997.

35. Antunes $\mathrm{F}$ and Cadenas E: Estimation of $\mathrm{H}_{2} \mathrm{O}_{2}$ gradients across biomembranes. FEBS Lett 475: 121-126, 2000.

36. Griffiths EJ: Mitochondria-potential role in cell life and death. Cardiovasc Res 46: 24-27, 2000.

37. Hara K, Kasahara E, Takahashi N, et al: Mitochondria determine the efficacy of anticancer agents that interact with DNA but not the cytoskeleton. J Pharmacol Exp Ther 337: 838-845, 2011.

38. Hou DX, Uto T, Tong X, et al: Involvement of reactive oxygen species-independent mitochondrial pathway in gossypol-induced apoptosis. Arch Biochem Biophys 428: 179-187, 2004.

39. Ko CH, Shen SC, Hsu CS and Chen YC: Mitochondrialdependent, reactive oxygen species-independent apoptosis by myricetin: roles of protein kinase $\mathrm{C}$, cytochrome $\mathrm{c}$, and caspase cascade. Biochem Pharmacol 69: 913-927, 2005.

40. Yamamori T, Yasui H, Yamazumi M, et al: Ionizing radiation induces mitochondrial reactive oxygen species production accompanied by upregulation of mitochondrial electron transport chain function and mitochondrial content under control of the cell cycle checkpoint. Free Radic Biol Med 53: 260-270, 2012. 